\title{
A COMPARATIVE STUDY OF ELEMENTARY SCHOOL TEACHERS COMPETENCY IN RELATION TO SEX AND AGE IN INDIA AND IRAN
}

Parvin Abbasi, * Abbas Madandar Arani*

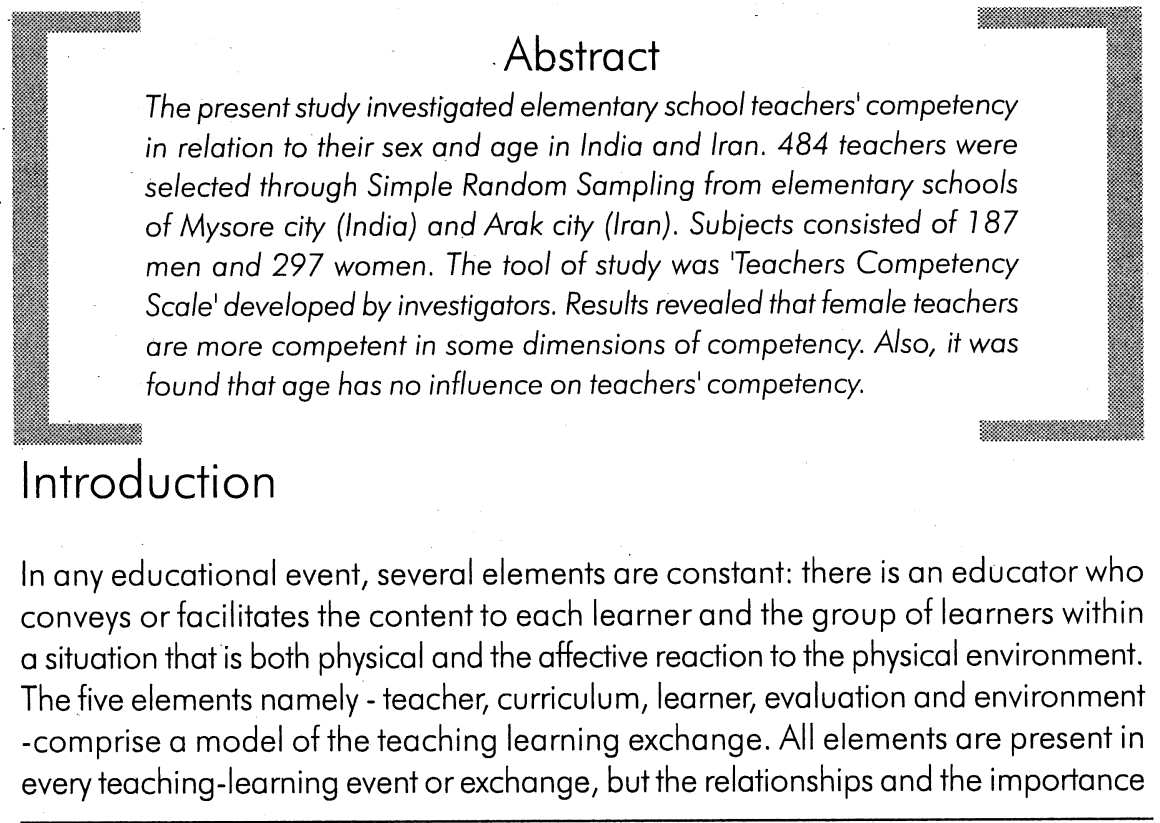

* Department of Education, University of Lorestan, Iran. 
of each component vary. (Heimlich \& Norland 2002). In recent years the public has come to believe that the key to educational improvement lies as much in upgrading the quality of teachers as in revamping school programs and curricula (Johnson, 1997). Indeed, of all the different factors, which influence the quality of education and its contribution to national development, the competency of teachers is undoubtedly the most significant, because the entire process of teaching - learning transaction in the classroom depends on the competency of a teacher. Medley (1982:21) states that the teacher competency as "those of knowledge, abilities and beliefs a teacher possesses and brings to the teaching situation". By this it is evident that the knowledge of subject matter, teaching skills, beliefs and feeling of teachers may be considered as the components of teaching competency that a competent teacher is supposed to possess.

However, as long ago as 1978 researchers felt that it was possible to identify what was meant by a good teacher; Brophy \& Good (1986) maintain that a good teacher is characterized as being: well organised, well prepared, involved in the subject, friendly, flexible, helpful, creative, clear, sensitive, interested in students, open, systematic and committed. Pinsky, Monson and Irby (1998) found that general principles of teaching excellence could be derived from their study. These principles include: involve learners, innovate continuously, create a positive atmosphere for learning, consider learners and context, engage learners, make careful preparation, limit content, engage in thoughtful self-analysis, be flexible, and use appropriate teaching strategies. Prahallada (2001) mentioned that the following qualities are required for a good and effective teacher: tact earnestness, ability to deal with subject matter, sound character and judgment, good health, love for students, personal attractiveness and good attitude. In fact there are four categories of teachers: A poor teacher who tells, an average teacher who explains, a good teacher who demonstrates and a great teacher who inspires. Lee (1996) found a significant positive linear correlation between teacher competencies and student competency. Also Nelson (1988) revealed that the competency of the teacher did affect the achievement of pupils in reading and math. However, since teaching is a prime component in any educational programme, evaluation of teaching competency is a necessary step to be contemplated upon. In the present study an attempt is made to find out the influence of sex and age on TC of Indian and Iranian teachers.

\section{Method}

\section{Sample}

From the 140 elementary schools in Mysore city and 120 elementary schools in Arak city, 86 schools were selected for the research work using Simple Random 
Sampling techniques (50 in Mysore and 36 in Arak). After choosing the schools, a sample of 484 elementary teachers (187 men and 297 women) was selected randomly from these schools and a list of their name along with the 'Teachers Competency Scale' was given to their headmasters/ headmistresses (86), to assess the competencies of selected teachers.

\section{Instrument}

The tool used in the present investigation was "Teachers Competency Scale" developed by authors. The Teachers Competency Scale measure competency of teachers as consisting of five components, viz, Teacher personality character (10 items), Teaching skills ( 12 items), Relation with students (10 items), Relation with fellow teachers (4 items) and School management (14 items). The scale consisted of 50 items distributed over five dimensions of teachers' competency. For Indian teachers, the original English versions and for Iranian teachers translated versions in Persian (by authors) were used. Initially, the Persian versions were administered as a pre-test to 25 male and 25 female Iranian teachers to find out the suitability of the instruments. With few minor revisions, main study was continued based on the suggestions given by the teacher of pretest. To score the items on the scale, measures of $4,3,2,1$, and 0 is given in case of positive statements, $0,1,2,3$, and 4 in case of negative statements. Each item is to be answered on a scale of five alternatives, i.e., $A=A l w a y s, O=$ Often, $S=$ Sometimes, VF = Very few and $N=$ Never. It was found that that the Teacher Competency Scale had a high reliability co-efficient of .716 and validity ranging from .574 to .807 , as indicated by split-half reliability.

\section{Procedure}

In India, the investigators personally visited all the selected schools and met the headmasters/ headmistresses for explaining purpose of the study and were instructed them how to respond to given tool i.e., Teachers Competency Scale. In cáse headmasters/ headmistresses had any doubts in understanding questions, investigators tried to make the questions clearer to them in their local languages. The same procedure has been done in Iran.

\section{Statistical Analysis}

Using SPSS (Windows version 10.0) statistical package, two way ANOVA was employed to find relationship between sub dimensions of teachers competency and teachers sex and age in both the countries - India and Iran. 


\section{Results}

Table 1 shows Mean scores for various dimensions of teacher competency with reference to Country, Sex and Age

\begin{tabular}{|c|c|c|c|c|}
\hline Variables & Sex and Age & Iran & India & Overall \\
\hline \multirow{7}{*}{$\begin{array}{l}\text { Teacher } \\
\text { personality } \\
\text { character }\end{array}$} & Male & 29.81 & 30.34 & 30.13 \\
\hline & Female & 31.08 & 31.30 & 31.16 \\
\hline & Below 30 years & 30.43 & 31.03 & 30.74 \\
\hline & $31-40$ years & 29.49 & 30.67 & 30.08 \\
\hline & $41-50$ years & 31.29 & 31.18 & 31.24 \\
\hline & 50 and above & 29.64 & 28.63 & 28.87 \\
\hline & Overall & 30.40 & 30.57 & 30.49 \\
\hline \multirow{7}{*}{ Teaching skills } & Male & 33.83 & 33.62 & 33.70 \\
\hline & Female & 36.39 & 33.93 & 35.50 \\
\hline & Below 30 years & 36.26 & 33.63 & 34.90 \\
\hline & $31-40$ years & 33.88 & 34.79 & 34.34 \\
\hline & $41-50$ years & 35.74 & 32.81 & 34.45 \\
\hline & 50 and above & 30.67 & 33.15 & 32.58 \\
\hline & Overall & 35.01 & 33.70 & 34.33 \\
\hline \multirow{7}{*}{$\begin{array}{l}\text { Relation with } \\
\text { students }\end{array}$} & Male & 28.67 & 28.34 & 28.47 \\
\hline & Female & 29.94 & 29.07 & 29.62 \\
\hline & Below 30 years & 30.66 & 28.98 & 29.79 \\
\hline & $31-40$ years & 28.24 & 28.68 & 28.46 \\
\hline & $41-50$ years & 29.11 & 28.31 & 28.76 \\
\hline & 50 and above & 29.67 & 27.78 & 28.21 \\
\hline & Overall & 29.26 & 28.52 & 28.87 \\
\hline \multirow{7}{*}{$\begin{array}{l}\text { Relation with } \\
\text { fellow teachers }\end{array}$} & Male & 10.75 & 11.39 & 11.13 \\
\hline & Female & 10.81 & 11.48 & 11.05 \\
\hline & Below 30 years & 10.93 & 11.58 & 11.27 \\
\hline & $31-40$ years & 10.79 & 11.18 & 10.99 \\
\hline & $41-50$ years & 10.72 & 11.58 & 11.10 \\
\hline & 50 and above & 10.25 & 11.30 & 11.06 \\
\hline & Overall & 10.77 & 11.41 & 11.10 \\
\hline \multirow{7}{*}{$\begin{array}{l}\text { School } \\
\text { management }\end{array}$} & Male & 37.95 & 33.63 & 37.16 \\
\hline & Female & 31.87 & 38.25 & 34.17 \\
\hline & Below 30 years & 37.69 & 36.14 & 37.89 \\
\hline & $31-40$ years & 33.75 & 37.51 & 35.66 \\
\hline & $41-50$ years & 34.59 & 37.12 & 35.70 \\
\hline & 50 and above & 35.00 & 37.37 & 36.83 \\
\hline & Overall & 35.15 & 37.03 & 36.12 \\
\hline
\end{tabular}


Tables 2 present results of two-way ANOVA for mean TC scores in various areas with reference to Country, Sex and Age.

\begin{tabular}{|c|c|c|c|}
\hline Variables & Source of variation & $\mathrm{F}$ & Significance \\
\hline \multirow{5}{*}{$\begin{array}{l}\text { Teacher personality } \\
\text { character }\end{array}$} & Between countries $(A)$ & .394 & .530 \\
\hline & Between sexes $(B)$ & 3.572 & .059 \\
\hline & Interaction $(\mathrm{A} \times \mathrm{B})$ & .072 & .788 \\
\hline & Between age groups $(B)$ & 1.698 & .167 \\
\hline & Interaction $(A \times B)$ & .501 & .681 \\
\hline \multirow{5}{*}{ Teaching skills } & Between countries $(A)$ & 3.448 & .064 \\
\hline & Between sexes (B) & 3.990 & .046 \\
\hline & Interaction $(A \times B)$ & 2.429 & .120 \\
\hline & Between age groups $(\mathrm{B})$ & 1.659 & .175 \\
\hline & Interaction $(\mathrm{A} \times \mathrm{B})$ & 2.978 & .031 \\
\hline \multirow{5}{*}{ Relation with students } & Between countries $(A)$ & .999 & .318 \\
\hline & Between sexes (B) & 2.716 & .100 \\
\hline & Interaction $(\mathrm{A} \times \mathrm{B})$ & .196 & .658 \\
\hline & Between age groups (B) & 1.272 & .283 \\
\hline & Interaction $(\mathrm{A} \times \mathrm{B})$ & .831 & .474 \\
\hline \multirow{5}{*}{$\begin{array}{l}\text { Relation with fellow } \\
\text { teachers }\end{array}$} & Between countries $(A)$ & 4.665 & .031 \\
\hline & Between sexes $(B)$ & .055 & .814 \\
\hline & Interaction $(\mathrm{AxB})$ & .002 & .968 \\
\hline & Between age groups $(\mathrm{B})$ & .331 & .803 \\
\hline & Interaction $(\mathrm{A} \times \mathrm{B})$ & .201 & .896 \\
\hline \multirow{5}{*}{ School management } & Between countries $(A)$ & 4.960 & .026 \\
\hline & Between sexes (B) & 3.876 & .050 \\
\hline & Interaction $(\mathrm{A} \times \mathrm{B})$ & 11.475 & .001 \\
\hline & Between age groups $(B)$ & .306 & .820 \\
\hline & Interaction $(\mathrm{A} \times \mathrm{B})$ & 1.274 & .283 \\
\hline
\end{tabular}

dfs for $A, B, A \times B=1,480$

\section{Between Countries}

The above tables indicate that in two dimensions of TC namely 'relation with fellow teachers' and 'school management' there is a significant difference between Indian and Iranian teachers. In these two dimensions, Indian headmasters/ headmistress rated female teachers significantly higher than other teachers. No differences were found between teachers in both the countries regarding the other dimensions of TC. 


\section{Between Genders}

In two dimensions of teacher competency there is a significant difference between male and female teachers. In dimensions like 'teaching skills' $(F=3.990)$ and 'school management' $(F=3.876)$, headmasters/ headmistress rated female teachers significantly higher than male teachers.

\section{Interaction effects}

The significant interaction effects between countries and genders indicate that in India headmasters/ headmistress rated female teachers significantly higher $(F=11.475)$ in one dimension of TC i.e. school management than other teachers. Results of the interaction effects for other dimensions of TC were found to be nonsignificant. From the above results, it could be concluded that there is a significant difference between male and female teachers competency whereas headmasters/ headmistresses informed female teachers have more competency than male teachers.

\section{Between Age groups}

Headmasters/ headmistress rated teachers with different age groups equally, which are statistically non-significant. Therefore, there is no difference between teachers with different age group and their competency.

\section{Interaction effect}

The interaction effects between countries and age groups for four dimensions of TC are found to be non-significant. Only in Teaching skills dimension, Iranian headmasters/ headmistresses rated teachers who are below 30 years of age significantly higher $(F=2.978)$ than other teachers.

\section{Discussion}

The main findings of the present study are:

- In two dimensions of TC namely 'relation with fellow teachers' and 'school management', Indian headmasters/ headmistresses rated female teachers are better compared to their counterparts.

- In both the countries there is a significant difference between male and female teachers in 'Teaching skills' and 'School management' dimensions of competency whereas headmasters/ headmistresses rated female teachers as having higher competency than male teachers. 
- In both the countries, age as such found to have no differential influence on teachers competency.

- In Iran, the headmasters/headmistress focused more on teaching skills as one of the dimension of teachers competency, and found that young teachers are better in teaching skills.

This study found that on three dimensions of TC namely 'teacher personality character', 'relation with students', and 'relation with fellow teachers' there is no difference between male and female teachers in both the countries. However, differences were noticed on other two dimensions namely 'teaching skills' and 'school management' between male and female teachers. Teaching skills refers to skills like present subject matter clearly to the students, develop pupil's interest in lesson, ability to use audio-visual aids, and use of new methods of teaching, which a good teacher must have for effective teaching, that is, teaching that leads to high student achievement. School management, refers to skills like hardworking, good communications, having team spirit, interest in co-curricular activities and good teacher- parent relationship. Headmasters/headmistresses in both the countries believe female teachers are better than male teachers in these two dimensions of competency. This is in contrary with findings of Macgregor (1995); Budzinsky (2000) who found that there is no effect of gender on teachers competency. Also, finding of this study is differed compared to research conducted by Saeed and Mahmood (2002) who found that competency level of female teachers was lower than their male counterparts.

Finding of this study reveals that there is no significant difference between teachers' competency and their age. This is supported by study of Carlson (1995) who found there is no relationship between teachers' age and level of competency. However, many authors highlighted that factors like gender and age depend upon countries, having different effects regarding teachers' competency. 


\section{References}

Brophy, J.E. \& Good, T.L. (1986) Teacher behaviour and student achievement. In M.C. Wittrock (Ed.), Handbook of research on teaching. New York: Macmillan

Budzinsky, F. K (2000) Beginning science teachers' performances: Assessment in times of reform. Thesis (Ph.D.) - The University of Connecticut. Dissertation Abstracts International. V: 61-04, Section: A, P.1346.

Carlson, D. L (1995) Perceptions held by Idaho Education Stakeholders concerning teacher competency testing and impact on minorities. Thesis (ED.D.)-University of Idaho. Dissertation Abstracts International. V: 57-01, Section: A, P: 0182

Heimlich, E. Norland, E (2002). Teaching Style: Where Are We Now? New Directions for Adult and Continuing Education, No.93.17-25

Johnson, B.L (1997). An Organizational Analysis of Multiple Perspectives of Effective Teaching: Implications for Teacher Evaluation. Journal of Personnel Evaluation in Education 11: 69-87

Lee, M,G.(1996). A Model for The Assessment of In-Service Education Using Data on the Acquisition of Human Genetics Concepts by Secondary Biology Teachers and Their Students and Implementation of Selected Teaching Strategies (High School Teachers). Thesis (ED.D.) - Ball State University. Dissertation Abstracts International. V: 57-03, Section: A, P. 1084.

Macgregor, E.R. (1995). Beginning Teachers in Florida's Public Schools: Perceptions of Success in The Florida Essential Generic Teaching Competencies and Job Satisfaction. Thesis (PH.D.) - University of South Florida. Dissertation Abstracts International. Volume: 56-12, Section: A, P.4739.

Medley, D.M (1982) Teacher effectiveness. In Harold E. Mitsel (Ed) Encyclopedia of Educational Research, New York: MacMillan publishing \&co, Vol IV

Nelson, B.C (1988). Relationships Between Teacher Competency and Pupil Achievement. Thesis (PH.D.), Claremont Graduate School Dissertation Abstracts International. V: 49-08, Section: A, P. 2055

Pinsky, L.E. Monson, D and Ibry, D.M (1998) How Excellent Teachers Are Made: Reflecting on Success to Improve Teaching, Advances in Health Sciences Education 3: $207-215$

Prahallada, N.N. (2001). Qualities of an effective teacher. The Primary Teacher Journal. NCERT. Vol. XXXI, (2) 58-61

Saeed, M. Mahmood, K (2002) Assessing competency of Pakistani primary school teachers in mathematics, science and pedagogy. The International Journal of Educational Management, 16 (4), 190 